\title{
Valacyclovir Hydrolase
}

National Cancer Institute

\section{Source}

National Cancer Institute. Valacyclovir Hydrolase. NCI Thesaurus. Code C20984.

Valacyclovir hydrolase (291 aa, $33 \mathrm{kDa}$ ) is encoded by the human BPHL gene. This protein is involved in the metabolism of both amino acid esters and nucleoside analogues. 